\title{
Faktor-Faktor yang Mempengaruhi Kejadian Stunting pada Anak: Studi Literatur
}

\author{
Slamet Ali Mashar ${ }^{1 *}$, Suhartono², Budiono ${ }^{2}$ \\ ${ }^{1}$ Prodi Magister Kesehatan Lingkungan, Fakultas Kesehatan Masyarakat Universitas Diponegoro, Semarang \\ ${ }^{2}$ Departemen Kesehatan Lingkungan, Fakultas Kesehatan Masyarakat, Universitas Diponegoro, Semarang
}

*Koresponden email: slamet.ari.mashar@gmail.com

Diterima: 30 Juni 2021

Disetujui: 6 Juli 2021

\begin{abstract}
Stunting is a global health problem and in Indonesia, both in urban and rural areas. Stunting occurs in children and if preventive actions are not taken such as nutrition, immunization, and maintain a clean environment, it may cause disturbances in children in brain development, body metabolism, and physical growth. Risk factors for stunting in children's parental habits , basic immunization, basic sanitation, history of infectious diseases, smoking habits, and upper respiratory tract infections. The purpose of this study is to provide information on factors that play a role in the risk of stunting according to a review study. This study uses a descriptive method with a literature review approach using previous research from the Sinta database. The review criteria used are indexed by Sinta 2, 3, 4, and 5, published times over the last 5 years. The conclusion of this literature review study is that there are several factors associated with the incidence of stunting such as the parenting habits of children, basic immunization, basic sanitation, history of infectious diseases, smoking habits, and incidence of respiratory infections.
\end{abstract}

Keywords: stunting, parenting, immunization, sanitation, exposure of cigarette smoke

\section{Abstrak}

Stunting menjadi masalah kesehatan di dunia dan Indonesia baik pada daerah perkotaan maupun perdesaan. Stunting terjadi pada anak dan apabila tidak dilakukan tindakan pencegahan seperti pemenuhan gizi, imunisasi, dan menjaga kebersihan lingkungan dapat menyebabkan anak terganggu perkembangan otak, metabolisme tubuh, dan pertumbuhan fisik. Faktor risiko terjadinya stunting pada anak seperti pola asuh orang tua terhadap anak, imunisasi dasar, sanitasi dasar, riwayat penyakit infeksi, kebiasaan merokok, dan infeksi saluran pernafasan atas (ISPA). Tujuan penelitian ini adalah memberi informasi terkait faktor yang memiliki peran sebagai risiko terjadinya stunting berdasarkan kajian review. Penelitian ini menggunakan metode deskriptif dengan pendekatan literatur review menggunakan penelitian terdahulu yang terdapat pada database Sinta. Kriteria jurnal yang digunakan terindeks Sinta 2, 3, 4, dan 5, waktu publikasi 5 tahun terakhir. Kesimpulan dalam penelitian literatur review ini adalah adanya beberapa faktor yang memiliki hubungan dengan kejadian stunting seperti pola asuh orang tua terhadap anak, imunisasi dasar, sanitasi dasar, riwayat penyakit infeksi, kebiasaan merokok, dan kejadian infeksi saluran pernafasan.

Kata Kunci: stunting, pola asuh, imunisasi, sanitasi, paparan asap rokok

\section{Pendahuluan}

Pertumbuhan dan perkembangan anak yang optimal merupakan indikator yang mencerminkan status gizi dan kesehatan penduduk suatu wilayah dan menjadi salah satu indikator kualitas sumber daya manusia. Sebagai indikator yang sensitif untuk mengetahui status gizi masyarakat adalah status gizi balita. Stunting merupakan kondisi yang disebabkan oleh kekurangan gizi kronis, sehingga stunting pada anak balita dapat menjadi indikator kunci kesehatan ibu dan bayi. Pertumbuhan linear terganggu, dan panjang tubuh tidak sesuai dengan usia dan dapat menyebabkan keterlambatan dalam tumbuh kembang anak. Defisit pertumbuhan linier ini disebabkan akumulasi asupan gizi dan nutrisi yang tidak optimal pada 1.000 hari pertama kehidupan [1].

Salah satu masalah yang dapat mempengaruhi kualitas hidup anak di masa yang akan datang adalah stunting. Keterlambatan perkembangan pada semua aspek anak dapat mempengaruhi perkembangan aspek kognitif dan fisik, penurunan produktivitas, kesehatan yang buruk, dan risiko penyakit degeneratif. Selain itu, stunting juga dapat menyebabkan peningkatan morbiditas dan mortalitas, penurunan kemampuan menyerap kursus, stunting menyebabkan masalah pada saat melakukan pekerjaan dan menurunkan pengeluaran rumah tangga sehingga sebagian besar hidup dengan kondisi kurang layak karena adanya masalah baik dalam keuangan maupun sosial [2]. 
Menurut Global Nutrition Report 2018, terdapat 150,8 juta (22,2\%) anak yang mengalami stunting di seluruh dunia. Organisasi Kesehatan Dunia (WHO) telah menetapkan tujuan penurunan angka stunting sebesar $40 \%$ pada tahun 2025. Bank Dunia memperhitungkan apabila tidak adanya tindakan untuk mengatasi permasalahan stunting di suatu negara, pendapatan per kapita penduduk dapat berkurang sebesar 7\% dan menurunkan pendapatan per kapita sekitar 9-10\% [2][3].

Hasil Riset Kesehatan Dasar (Riskesdas) mengemukakan bahwa proporsi anak pendek di Indonesia tidak mengalami penurunan yang signifikan. Jumlah kasus stunting mengalami penurunan pada tahun 2007 ke 2010 dari $37,6 \%$ ke 35,8\%. lalu terjadi peningkatan di tahun 2013 menjadi 37,2\% dan mengalami penurunan pada tahun 2018 sebesar 29,9\%. Permasalahan malnutrisi di Indonesia mengurangi potensi ekonomi sebesar 0,04 sampai dengan 0,16\% dari Produk Domestik Bruto Stunting di Indonesia [3][4][5].

Intervensi sangat diperlukan dalam menanggulangi kejadian stunting. Pencegahan dapat dilakukan saat 1000 Hari Pertama Kehidupan (1000 HPK). Anak yang telah melewati 1000 HPK dengan diberikan dengan gizi dan nutrisi yang cukup serta menjaga sanitasi dengan baik menurunkan risiko terjadinya stunting. Penelitian yang dilakukan di Burkin Faso, Afrika Barat mendapatkan kesimpulan bahwa lingkungan yang tidak terurus dan pemberian asupan makanan yang salah memiliki hubungan dengan terjadinya stunting pada anak.[6]

Orang tua memiliki peran yang besar sebagai tindak pencegahan stunting, berdasarkan penelitian Zenderi (2020), Asweros (2020), Ayu (2020), Nasrul (2020), Himawati (2020), Elisabeth (2020), Sutriyawan (2020), Solin (2019), Novianti (2020), Desyanti (2017), Rahmawati (2021) dan didapatkan kesimpulan bahwa stunting memiliki berbagai faktor yang memicu terjadinya stunting seperti seperti pola asuh orang tua terhadap anak, imunisasi dasar, sanitasi dasar, riwayat penyakit infeksi, kebiasaan merokok, dan infeksi saluran pernafasan atas (ISPA) [3], [6]-[15]. Berdasarkan penjelasan masalah mengenai faktor risiko terjadinya stunting, maka peneliti memiliki ketertarikan untuk membahas faktor-faktor yang dapat menjadi risiko terjadinya stunting pada anak menggunakan kajian review dari peneliti-peneliti terdahulu.

\section{Metode Penelitian}

Penulisan ini menggunakan metode literatur review dimana literatur review merupakan penelitian yang menggunakan studi data sekunder yang diperoleh dari berbagai jurnal penelitian sehingga kualitas artikel review yang dihasilkan berkualitas tinggi. Seluruh jurnal yang digunakan merupakan hasil penyaringan menggunakan kriteria inklusi dan eksklusif guna mempersempit ruang kajian. Kriteria inklusi jurnal yang digunakan adalah:

1. Jurnal terakreditasi Sinta 2,3,4, dan 5

2. Merupakan keluaran 5 tahun terakhir

3. Memiliki tema tentang stunting

Kriteria eksklusi jurnal yang digunakan adalah:

1. Tidak memiliki akreditasi sinta

2. Tema tidak memiliki hubungan dengan kejadian stunting

Artikel ini memberikan gambaran faktor yang mempengaruhi kejadian stunting pada anak dengan menggunakan jurnal-jurnal yang memenuhi kriteria untuk digunakan dalam artikel review ini.

Tabel 1. Daftar jurnal yang menjadi materi review

\begin{tabular}{|c|c|c|c|c|}
\hline Sumber & $\begin{array}{c}\text { Nama Penulis, Tahun } \\
\text { Terbit }\end{array}$ & Penerbit & $\begin{array}{l}\text { Indeks } \\
\text { Sinta }\end{array}$ & Temuan dalam Penelitian \\
\hline 1. & $\begin{array}{l}\text { Erni Rukmana, Dodik } \\
\text { Briawan, Ikeu Ekayanti, } \\
2016\end{array}$ & $\begin{array}{l}\text { Media Kesehatan } \\
\text { Masyarakat } \\
\text { Indonesia, Universitas } \\
\text { Hasanuddin }\end{array}$ & 2 & $\begin{array}{l}\text { 1. Terdapat hubungan } \\
\text { antara BBLR dan } \\
\text { pendidikan orang tua } \\
\text { yang rendah dengan } \\
\text { kejadian stunting } \\
\text { 2. Pendapatan keluarga } \\
\text { yang tinggi } \\
\text { memungkinkan untuk } \\
\text { mendapatkan pangan } \\
\text { yang bagus untuk } \\
\text { memenuhi kebutuhan } \\
\text { keluarga }\end{array}$ \\
\hline
\end{tabular}




\section{Sutarni Rachmawati, Putri Media Kesehatan Bungsu Machmud, 2019 Masyarakat \\ Indonesia, Universitas \\ Hasanuddin}

3.

Zenderi Wardani, Dadang Media Kesehatan Sukandar, Yayuk F. Masyarakat Baliwati, Hadi Riyadi, Indonesia, Universitas 2020

Hasanuddin

4. Asweros Umbu Zogara, Jurnal Ilmu Kesehatan Maria Goreti Pantaleon, Masyarakat, Sekolah 2020

Tinggi Ilmu

Kesehatan

5.

$\begin{array}{lrlr}\text { Niken Ayu Merna } & \text { Eka } & \text { Jurnal } & \text { Ilmu } \\ \text { Sari, Ni Komang } & \text { Ayu } & \text { Keperawatan Anak, } \\ \text { Restiayu, 2020 } & & \text { Sekolah Tinggi } & \text { Ilmu } \\ & & \text { Kesehatan } & \text { Wira } \\ & & \text { Medika Bali } & \end{array}$

6.

Nasrul, Fahmi Hafid, A. Media Kesehatan Razak Thaha, Suriah, 2016 Masyarakat Indonesia, Universitas Hasanuddin

7.

Dayuningsih, Tria Astika Endah Permatasari, Nana Supriyatna

Jurnal Kesehatan Masyarakat Andalas, Universitas Andalas

8. Nina Fentiana, Sinarsih,
2018
Jurnal Kesehatan

Masyarakat

Khatulistiwa,

Universitas Sari

Mutiara Indonesia

Medan

\section{2}

1

4
Adanya pengaruh antara variabel interaksi praktik kesehatan dan pendidikan ibu dengan kejadian stunting

1. Prediktor yang menyebabkan stunting pada anak antara lain layanan sanitasi yang kurang layak dan kebiasaan merokok.

1. Faktor terjadinya stunting pada anak dalam penelitian ini adalah pola ash orang tua dan pemberian nutrisi yang kurang.

1. Perilaku merokok pada orang tua menimbulkan dampak secara langsung dari kandungan nikotin dan timbal yang mempengaruhi proses pertumbuhan anak, sedangkan dampak tidak langsung antara lain kemampuan orang tua untuk memenuhi kebutuhan gizi anak

2 1. Berat Badan Lahir Rendah, tinggi badan ibu rendah, dan tidak mencuci tangan menggunakan sabun merupakan faktor risiko stunting pada anak

2. Asupan gizi yang kurang baik saat masa hamil merupakan faktor penyebab terjadinya Berat Badan Lahir Rendah

1. BBLR memiliki hubungan yang bermakna dengan kejadian stunting, faktor yang paling dominan pola asuh pemberian makan.

4 1. Asupan kalori dan nutrisi yang rendah merupakan faktor risiko stunting pada balita. 


$\begin{array}{ll}\text { Ernia Haris Himawati, } & \text { Jurnal Kesehatan } \\ \text { Laila Fitria, 2020 } & \text { Masyarakat } \\ & \text { Indonesia, Universitas } \\ & \text { Muhammadiyah } \\ & \text { Semarang }\end{array}$

\section{0.}

Jasman, Apoina Kartini,
Martini, 2020
Agustini Elisabet, Elvi
Juliansyah, 2020

Visikes

Kesehatan,

Jurnal

Universitas

Nuswantoro

11. Agustini Elisabet
Juliansyah, 2020

\section{2.}

$\begin{array}{lrlr}\text { Agung } & \text { Sutriyawan, } & \text { Jurnal Kesehatan } \\ \text { Chantika } & \text { Cindiana } & \text { Masyarakat } \\ \text { Nadhira, 2020 } & & \text { Khatulistiwa, } \\ & \text { Universitas Sari } \\ & \text { Mutiara Indonesia } \\ & \text { Medan }\end{array}$

13. Angina Rohdalya Solin, Jurnal Ners Indonesia, Oswati Hasanah, Sofiana Universitas Riau Nurchayati, 2019

14. Siti Nurhasiyah Jamil, Jurnal Bidan Cerdas, Aning Subiyatin, 2020

Politeknik Kesehatan Palu

15. Agung Sutriyawan, Ratna Journal of Midwifery, Dian Kurniawati, Sri Universitas Andalas Rahayu, Julius Habibi, 2020

16. Chamilia Desyanti, Triska Susila Nindya, 2017
Amerta Nutrition, Universitas Airlangga
. Riwayat
memiliki hubungan
yang signifikan
dengan kejadian
stunting

2. Diare dan BBLR

berperan sebagai

perancu antara

hubungan ISPA

dengan stunting

sehingga ISPA tidak

berhubungan dengan stunting.

1. Faktor risiko yang ditemukan pada

penelitian ini antara

lain paparan pestisida

dan tinggi badan ibu rendah

1. Faktor risiko stunting pada penelitian ini antara lain pola asuh, tradisi, dan akses informasi yang kurang.

1. Faktor risiko terjadinya stunting dalam penelitian ini adalah pengetahuan ibu, ASI eksklusif, dan sanitasi dasar

2. Balita yang tinggal di rumah dengan sanitasi dasar yang tidak memenuhi syarat berpeluang 6 kali lebih besar mengalami kejadian stunting

3 1. Infeksi Saluran

Pernapasan Atas dan

Diare merupakan

faktor risiko terjadinya stunting.

4 1. Terdapat hubungan antara riwayat imunisasi dengan kejadian stunting pada anak

4 1. Faktor risiko terjadinya stunting pada anak dalam penelitian ini antara lain imunisasi yang tidak lengkap, riwayat diare dan ISPA.

1. Praktik higiene yang kurang baik dan diare merupakan faktor risiko terjadinya stunting 


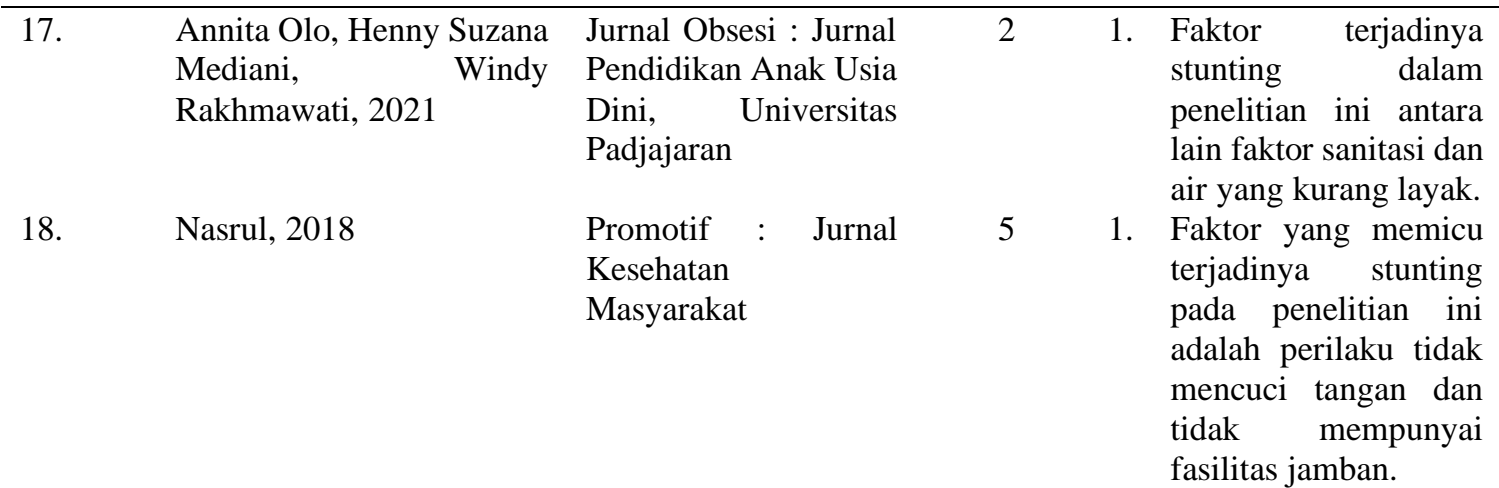

Adapun ciri-ciri penerbit jurnal penelitian yang digunakan sebagai sampel dan referensi dalam kajian review. Terdapat 18 jurnal yang diletakkan pada Tabel 1 dan digunakan sebagai sampel penelitian karena memenuhi kriteria inklusi dan eksklusi. Terdapat berbagai macam faktor yang mempengaruhi kejadian stunting seperti pola asuh orang tua, imunisasi dasar, sanitasi dasar, riwayat penyakit infeksi, paparan asap rokok, dan kejadian infeksi saluran pernapasan.

\section{Hasil dan Pembahasan}

\section{Hubungan antara Pola Asuh Orang Tua dengan Kejadian Stunting}

Salah satu faktor risiko terjadinya stunting adalah pola asuh orang tua terhadap anak-anaknya yang diartikan rasa kasih sayang dan perhatian yang melekat pada anak dengan merawat, membina, dan mendidik anak pada usia dimana mereka tidak bisa melakukan semuanya sendiri dan membutuhkan pertolongan orang lain. Rahmawati melakukan penelitian pada Tahun 2020 dan mendapatkan kesimpulan bahwa faktor risiko terjadinya stunting adalah pola asuh yang kurang karena anak tersebut tidak terpenuhi asupan gizi dan nutrisinya. Penelitian Rahmawati sejalan dengan Kasim (2019) yang menjelaskan adanya hubungan antara pola asuh dengan kejadian [16][17].

Menurut UNICEF, pola asuh orang tua merupakan salah satu faktor penyebab terjadinya stunting selain kualitas pelayanan kesehatan, kualitas lingkungan, dan ketahanan pangan. Pola asuh yang baik teridiri dari Inisiasi menyusui dini, ASI eksklusif dan makanan pendamping ASI, dengan tiga hal tersebut, anak yang dirawat memiliki risiko kecil untuk mengalami stunting [4][16]. Pola asuh orang tua dipengaruhi oleh pengetahuan dimana pengetahuan tersebut ditentukan oleh informasi yang diperoleh dari lingkungan baik media masa ataupun sosial media, kader, maupun tenaga kesehatan lainnya. Salah satu upaya yang telah dilakukan untuk menekan angka stunting adalah melalui penguatan kapasitas kader di tingkat komunitas dalam melakukan upaya sosialisasi mengenai pencegahan stunting pada orang tua.

Selain itu, dukungan keluarga merupakan faktor utama yang memengaruhi perilaku ibu dalam pengambilan suatu keputusan untuk meningkatkan kesehatan balita seperti pemberian imunisasi, disamping pola asuh pada anak [18][19]. Kementerian Kesehatan memberikan informasi terkait faktor risiko stunting yaitu praktik pengasuhan yang tidak baik dan hal tersebut sangat berpengaruh pada 1000 hari pertama kelahiran. Pencegahan stunting dapat dilakukan dengan keterlibatan masyarakat dan memperdalam pengetahuan terkait pola asuh anak [4][16].

\section{Hubungan antara Imunisasi Dasar dengan Kejadian Stunting}

Vaksinasi memiliki peran penting dalam menekan mortalitas anak dan menekan risiko anak untuk mengalami stunting. Vaksinasi yang dilakukan tepat waktu dapat mengurangi kemungkinan stunting pada anak, sementara vaksinasi yang tertunda dapat meningkatkan kemungkinan stunting karena imunisasi dalam sistem kesehatan merupakan bentuk intervensi kesehatan yang sangat efektif dalam upaya menekan angka kesakitan dan kematian balita [20].

Nasrul melakukan penelitian pada tahun 2016 dan mendapatkan kesimpulan anak yang tidak melakukan imunisasi 1,6 kali lebih berisiko stunting dibandingkan dengan anak yang melakukan imunisasi. Hal ini sejalan dengan penelitian yang dilakukan oleh Picauly tahun 2013 dan menyimpulkan bahwa anak yang tidak melakukan imunisasi 1,9 kali lebih berisiko untuk stunting dibandingkan dengan anak yang melakukan imunisasi. Kebanyakan responden dalam penelitian tidak mendapat imunisasi lengkap karena minimnya pengetahuan orang tua mengenai pentingnya imunisasi [9][21][22]. 1000 HPK merupakan hal yang sangat penting untuk masa depan anak karena apabila terdapat kesalahan orang tua dalam membuat keputusan maka akibat yang dirasakan oleh anak dapat dirasakan seumur hidup, oleh karena itu orang tua perlu diedukasi untuk tidak telat memberikan vaksinasi kepada anaknya [9][21]. 
Imunisasi pada anak merupakan hal yang sangat penting untuk meningkatkan daya tahan tubuhnya. Apabila tidak dilakukan maka akan meningkatkan risiko terserang penyakit infeksi dan menyebabkan nafsu makan menurun dan mengalami gangguan absorbsi zat gizi yang menyebabkan asupan nutrisi yang diterima sangatlah sedikit. Zat mikro dan makro pada usia 2 tahun pertama kehidupan merupakan hal yang sangat penting untuk mendukung pertumbuhan anak.[12], [23]

Status imunisasi pada anak merupakan indikator bahwa telah menjalin kontak dengan tenaga kesehatan maupun pelayanan kesehatan, maka dari itu melakukan imunisasi secara lengkap akan memperbaiki masalah gizi baru, sehingga status imunisasi juga diharapkan akan memberikan efek positif terhadap status gizi anak untuk jangka panjang [20]. Meskipun telah melakukan imunisasi tidak berarti balita tersebut bebas dari stunting karena terdapat beberapa faktor lain yang menyebabkan stunting seperti pola asuh orang tua, sanitasi dasar, sumber air minum, penyakit infeksi seperti diare atau saluran pernapasan, dan paparan asap rokok pada anak.

\section{Hubungan antara Sanitasi dan Higiene Dasar dengan Kejadian Stunting}

Sanitasi dasar merupakan salah satu faktor risiko terjadinya stunting. Praktik higiene menjadi salah satu hal yang penting dalam menjaga kesehatan anak. Mencuci tangan dengan air mengalir, mencuci makanan sebelum diolah, mencuci tangan saat mengolah makanan, mencuci tangan sebelum menyusui, dan mencuci tangan setelah buang air besar merupakan salah satu tolak ukur yang mengukur perilaku hidup bersih tiap individu. Mencuci tangan dengan air mengalir memiliki kaitan dengan kejadian stunting dan pencegahan diare pada anak [9].

Fasilitas Air, sanitasi, serta perilaku yang buruk dapat memicu terjadinya diare, cacingan atau enteropati, infeksi pada usus yang berdampak pada status gizi anak. Infeksi dalam kondisi ini secara langsung mempengaruhi status gizi melalui hilangnya nafsu makan, pencernaan yang buruk, malabsorpsi nutrisi, aktivasi kekebalan kronis, dan infeksi yang mengalihkan penggunaan zat gizi dan energi seperti demam.[24]

Torlesse melakukan penelitian pada tahun 2016 dan menemukan bahwa terdapat interaksi yang signifikan antara sanitasi rumah, pengolahan air rumah tangga dengan stunting [25]. Angka kejadian stunting pada anak yang tidak memiliki jamban lebih tinggi $(35,3 \%)$ dibandingkan anak yang memiliki jamban (24\%). Sementara perbandingan keluarga yang tidak menggunakan sabun saat mencuci tangan $(31,6 \%)$ lebih tinggi dibandingkan dengan keluarga yang menggunakan sabun saat mencuci tangan $(25,8 \%)$, dan yang terakhir adalah keluarga yang menggunakan air tanpa diolah lebih tinggi $(38,2 \%)$ dibandingkan dengan yang mengolah air $(27,3 \%)$, sehingga kebersihan pada rumah dan individu masingmasing cenderung buruk dan dapat meningkatkan risiko terjadinya penyakit seperti diare yang dapat meningkatkan kemungkinan terjadinya stunting pada anak [24][25].

Tidak tersedianya fasilitas sanitasi pada tingkat perumahan menyebabkan anggota keluarga tidak mendapatkan layanan sanitasi yang layak dan menyebabkan perilaku tidak mencuci tangan dengan benar setelah buang air besar dan menyiapkan atau memberikan makanan pada anak sehingga meningkatkan risiko masuknya kotoran atau bakteri ke dalam tubuh anak dan menyebabkan anak sakit.

\section{Hubungan antara Penyakit Diare dengan Kejadian Stunting}

Diare merupakan ke dalam faktor risiko terjadinya stunting pada anak yang menjadi masalah kesehatan di Indonesia. Diare disebabkan oleh berbagai alasan seperti infeksi Shigella sp., Salmonella, Campylobacter, dan Escherichia coli. Selain itu, faktor pemicu terjadinya diare adalah intoleransi terhadap zat yang ada pada makanan seperti laktosa dan fruktosa, alergi terhadap suatu makanan, efek samping dari obat, geografis suatu wilayah, tingkat sanitasi dan kebersihan [26].

Anak berusia 2 tahun lebih sering mengalami diare karena usus yang lebih peka terhadap zat-zat yang masuk ke dalam makanan. Diare merupakan penyakit menular yang ditandai dengan perubahan bentuk tinja yang menjadi lunak, frekuensi buang air besar meningkat, serta disertai dengan muntahmuntah, sehingga mengakibatkan kekurangan cairan dalam tubuh penderita atau dehidrasi berat. Terakhir, jika tidak segera mendapatkan pertolongan dapat mengakibatkan masalah kesehatan yang serius bahkan kematian [25] [27].

Penelitian yang dilakukan oleh Desyanti pada tahun 2017 didapatkan kesimpulan bahwa riwayat diare memiliki risiko sebesar 3,619 kali lebih besar terhadap kejadian stunting pada anak balita karena praktik higiene, pola asuh, mikroorganisme pada air, dan bahan kimia lainnya [15]. Penelitian ini sejalan dengan penelitian Aguayo \& Zul Fikar yang menjelaskan bahwa anak dapat terkena diare karena mikroorganisme pada air dan bahan kimia lainnya dan menyebabkan stunting karena mengalami kehilangan cairan serta sejumlah zat gizi yang esensial bagi tubuh [28][29].

Salah satu faktor risiko terjadinya diare adalah Perilaku Hidup Bersih dan Sehat (PHBS). PHBS dipengaruhi oleh banyak faktor seperti tingkat pengetahuan dan upaya memperbaiki perilaku hidup bersih 
dan sehat. Pengetahuan yang meningkat akan mempengaruhi pola pikir seseorang untuk memperbaiki pola hidup supaya dapat meningkatkan derajat kesehatan khususnya untuk menghindari hal-hal yang dapat memicu kejadian diare [4][26].

\section{Hubungan antara Perilaku Merokok dengan Kejadian Stunting}

Asap rokok mengandung berbagai macam kandungan kimia yang dapat menyebabkan mutasi dan kanker pada seseorang yang menghirupnya. Ketika terpapar rokok dalam jangka waktu yang lama, bahanbahan kimia khususnya nikotin, tar, dan karbon monoksida menyebabkan tersumbatnya pembuluh darah. Ketika arteri daerah tersumbat, zat-zat yang dibutuhkan oleh tubuh untuk melakukan metabolisme menjadi tidak seimbang. Apabila terjadi ketidakseimbangan maka tubuh lebih rentan terkena penyakit. Anak yang menjadi perokok pasif dimungkinkan memiliki dampak yang sama dengan perokok aktif. Penelitian yang dilakukan oleh Ayu pada tahun 2020 ditemukan bahwa perilaku merokok orang tua dapat mempengaruhi kejadian stunting pada anak karena paparan zat kimia yang diterima langsung oleh anak dapat mengubah metabolisme tubuh anak sehingga mengalami kecacatan. Penelitian ini sejalan dengan penelitian Budiastutik pada tahun 2019 yang menjelaskan bahwa paparan asap rokok maupun polusi asap diduga berpengaruh terhadap kejadian stunting [8][30].

Kebiasaan merokok yang dilakukan orang tua memiliki dampak negatif terhadap tumbuh kembang anak. Pertama, merokok memiliki dampak langsung terhadap pertumbuhan dan perkembangan anak-anak mereka dengan cara mengganggu penyerapan nutrisi pada anak yang nantinya akan mengganggu pertumbuhan dan perkembangannya. Kedua, karena tingginya harga rokok, orang tua terpaksa mengurangi pengeluaran lain seperti untuk membeli makanan bergizi, untuk pelayanan kesehatan, dan pendidikan. Orang tua yang minim pengetahuan akan cenderung memilih untuk membeli rokok dibandingkan dengan memenuhi kebutuhan asupan nutrisi sang anak sehingga mengakibatkan keterlambatan perkembangan mental. Selain itu, dampak yang ditimbulkan dari kebiasaan merokok adalah meningkatkan angka kesakitan dan angka kematian karena kerentanan anak terhadap penyakit [10].

Hasil penelitian Ayu pada tahun 2020 menunjukkan bahwa perilaku merokok pada orangtua terutama ayah akan mempengaruhi proses pertumbuhan dari anak baik secara langsung maupun tidak langsung. [8] Kebiasaan untuk mengkonsumsi rokok akan menyebabkan anak terpapar kandungan zat kimia yang berbahaya dari rokok yang akan menghambat pertumbuhan. Biaya untuk membeli rokok juga akan mengurangi biaya untuk pemenuhan kebutuhan belanja dalam rumah tangga sehingga asupan gizi yang harapannya bisa diberikan dengan baik kepada anak tidak terwujud dengan baik [8][14]. Dalam penelitian ini, paparan asap rokok merupakan salah satu masalah penting yang menyebabkan stunting pada anak karena zat kimia yang dihasilkan dapat memberikan efek langsung pada anak maupun efek tidak langsung. Oleh karena itu diperlukannya edukasi mengenai pentingnya tidak merokok dan dampak negatif yang dihasilkan dari asap rokok yang terhirup.

\section{Hubungan antara Kejadian ISPA dengan Kejadian Stunting}

Infeksi Saluran Pernapasan Atas (ISPA) merupakan salah satu penyakit yang banyak dijumpai pada anak dengan gejala ringan sampai berat dan menjadi isu kesehatan global. Seseorang dapat terjangkit Infeksi Saluran Pernapasan Atas karena menghirup udara, virus atau bakteri yang dihembuskan oleh penderita kepada orang lain. ISPA berat terjadi jika infeksi sampai ke jaringan paru dan mengakibatkan pneumonia, penyebab kematian besar pada anak. Penelitian yang dilakukan oleh Lestari pada tahun 2014 menemukan bahwa di Aceh anak dengan riwayat ISPA berpeluang 5.7 kali mengalami stunting [31].

Kemudian penelitian Bening tahun 2018 di kota Semarang, asupan zinc dan ISPA menjadi faktor risiko stunting dengan besar risiko masing-masing 9,2 dan 2,4 [32]. Selain ISPA, faktor-faktor lain yang berhubungan dengan stunting adalah riwayat penyakit infeksi seperti diare, perilaku hygiene dan sanitasi, status gizi ibu, paparan asap rokok, dan anak serta faktor sosio ekonomi [10]. Infeksi Saluran Pernapasan Atas sendiri merupakan penyakit infeksi yang menjadi penyebab mortalitas dan morbiditas tertinggi pada anak di Indonesia. Kejadian ISPA dapat mempengaruhi sistem metabolisme tubuh dan menyebabkan nafsu anak berkurang sehingga asupan nutrisi tidak terpenuhi [32][33].

Berdasarkan hasil penelitian di atas, peneliti berasumsi bahwa perilaku merokok pada orangtua tidak hanya berdampak negatif pada individu tersebut tetapi juga kepada keluarga dan orang sekitar. Kadar nikotin yang terkandung dalam rokok dapat menyebabkan gangguan kesehatan pada sistem respirasi dan menimbulkan komplikasi juga pada organ lainnya. Paparan timbal juga akan mempengaruhi kesehatan ibu hamil dan janinnya, yang nantinya akan mempengaruhi berat badan bayi saat dilahirkan.

Anak dengan ISPA akan mengalami gangguan metabolisme di dalam tubuhnya akibat peradangan yang terjadi. Sistem regulasi sitokin proinflammatory dapat mempengaruhi kondrosit secara langsung. Sehingga akan berdampak kepada proses pembentukan tulang. Balita merupakan fase pertumbuhan dan perkembangan yang sangat penting dan berlangsung dengan cepat. Karena setelah memasuki usia sekolah, 
proses pertumbuhan dan perkembangan akan mulai menurun. Dengan demikian, apabila anak mempunyai riwayat penyakit ISPA, proses pertumbuhan dan perkembangannya akan terganggu [8].

\section{Kesimpulan}

Hasil kajian review sejumlah artikel penelitian menemukan bahwa pola asuh, imunisasi dasar, sanitasi dan higiene dasar, penyakit diare, kebiasaan merokok, dan infeksi saluran pernapasan atas merupakan faktor risiko stunting. Hasil yang ditemukan oleh peneliti lain dapat dijadikan referensi untuk perencanaan penyelesaian stunting melalui modifikasi faktor lingkungan dan peningkatan pengetahuan, pendekatan masyarakat dengan bantuan tenaga kesehatan terdekat untuk memberikan pengetahuan, sikap, dan praktik untuk menjaga sanitasi di dalam maupun luar rumah.

Peneliti mengajukan saran untuk pihak layanan kesehatan terdekat seperti Puskesmas memaksimalkan program untuk meminimalisir terjadinya stunting seperti imunisasi sesuai dengan standar nasional dan melakukan screening terhadap balita yang mengalami penyakit infeksi guna melakukan pencegahan sejak dini. Masyarakat juga disarankan untuk memeriksakan anaknya setiap ada pemeriksaan dari pelayanan kesehatan untuk memantau tumbuh kembang anak.

\section{Ucapan Terimakasih}

Terimakasih kepada Departemen Kesehatan Lingkungan, Fakultas Kesehatan Masyarakat Universitas Diponegoro yang telah mendukung kami selama proses pengerjaan artikel. Semoga artikel ini dapat berguna untuk banyak orang dan dapat dijadikan referensi dalam pembuatan literatur review.

\section{Daftar Pustaka}

[1] E. Rukmana, D. Briawan, and I. Ekayanti, "Risk Factors Stunting in Children Aged 6-24 Months in Bogor," J. MKMI2, vol. 12, no. 3, pp. 192-199, 2016.

[2] W. B. WHO, UNICEF \& Group, "Levels and Trends in Child Malnuutrition," pp. 1-16, 2018.

[3] Z. Wardani, D. Sukandar, Y. F. Baliwati, and H. Riyadi, "Akses Sanitasi, Merokok dan Annual Parasite Incidence Malaria sebagai Prediktor Stunting Baduta di Indonesia," Media Kesehat. Masy. Indones., vol. 16, no. 1, p. 127, 2020.

[4] Kemenkes RI, "Hasil Riset Kesehatan Dasar Tahun 2018," Kementrian Kesehat. RI, vol. 53, no. 9, pp. 1689-1699, 2019.

[5] B. S. Renyoet, D. Martianto, and D. Sukandar, "Potensi Kerugian Ekonomi Karena Stunting Pada Balita Di Indonesia Tahun 2013,” J. Gizi dan Pangan, vol. 11, no. 3, pp. 247-254, 2016.

[6] U. Z. Asweros, "Jurnal Ilmu Kesehatan Masyarakat Jurnal Ilmu Kesehatan Masyarakat,” vol. 9, no. 2, 2020.

[7] W. R. Annita Olo, Henny Suzana Mediani, "Hubungan Faktor Air dan Sanitasi dengan Kejadian Stunting pada Balita di Indonesia," J. Obs. J. Pendidik. Anak Usia Dini, vol. 5, no. 2, pp. 10351044, 2020.

[8] N. Ayu, M. Eka, N. Komang, A. Resiyanthi, J. Data, and I. Kintamani, "Kejadian Stunting Berkaitan Dengan Perilaku Merokok Orang Tua mengetahui "Kejadian Stunting Berkaitan kuantitatif yang menggunakan desain orangtua balita di Wilayah kerja Puskesmas 57 orang. Penelitian ini menggunakan univariat data yang diperoleh dari," J. Ilmu Keperawatan Anak, vol. 3, no. 2, pp. 24 30, 2020.

[9] Nasrul, F. Hafid, A. Razak Thaha, and Suriah, "Faktor Risiko Stunting Usia 6-23 Bulan di Kecamatan Bontoramba Kabupaten Jeneponto," Media Kesehat. Masy. Indones., vol. 11, no. 3, pp. 139-146, 2015.

[10] E. H. Himawati and L. Fitria, "Hubungan Infeksi Saluran Pernapasan Atas dengan Kejadian Stunting pada Anak Usia di Bawah 5 Tahun di Sampang," J. Kesehat. Masy. Indones., vol. 15, no. 1, p. 1, 2020.

[11] J. E. Elisabeth A., "Faktor Risiko Kejadian Stunting pada Balita di Wilayah Kerja Puskesmas Pandan Kabupaten Sintang," Visikes, vol. 20, no. 1, 2021.

[12] A. Sutriyawan, R. D. Kurniawati, S. Rahayu, And J. Habibi, "Hubungan Status Imunisasi Dan Riwayat Penyakit Infeksi Dengan Kejadian Stunting Pada Balita: Studi Retrospektif," J. Midwifery, vol. 8, no. 2, pp. 1-9, 2020.

[13] A. R. Solin, O. Hasanah, and S. Nurchayati, "Hubungan Kejadian Penyakit Infeksi Terhadap Kejadian Stunting Pada Balita 1-4 Tahun," JOM FKp, vol. 6, no. 1, pp. 65-71, 2019.

[14] S. Novianti and R. S. Padmawati, "Hubungan faktor lingkungan dan perilaku dengan kejadian stunting pada balita : scoping review," J. Kesehat. komunitas Indones., vol. 16, no. 1, pp. 153-164, 
2020.

[15] C. Desyanti and T. S. Nindya, "Hubungan Riwayat Penyakit Diare dan Praktik Higiene dengan Kejadian Stunting pada Balita Usia 24-59 Bulan di Wilayah Kerja Puskesmas Simolawang, Surabaya," Amerta Nutr., vol. 1, no. 3, p. 243, 2017.

[16] L. A. Rahmawati, F. R. Hardy, A. Anggraeni, and D. Purbasari, "Faktor-Faktor yang Berhubungan dengan Stunting Sangat Pendek dan Pendek pada Anak Usia 24-59 Bulan di Kecamatan Sawah Besar Related Factors of Very Short and Short Stunting In Children Aged 24 - 59 Months in Kecamatan Sawah Besar," J. Ilm. Kesehat. Masy., vol. 12, no. 2, pp. 68-78, 2020.

[17] E. Kasim, N. Malonda, and M. Amisi, "Hubungan Antara Riwayat Pemberian Imunisasi dan Penyakit Infeksi dengan Status Gizi pada Anak Usia 24-59 Bulan di Kecamatan Ratahan Kabupaten Minahasa Tenggara. (Relationship Between History of Immunization and Infectious Disease with Nutritional Status i," J. Bios Logos, vol. 9, no. 1, p. 34, 2019.

[18] T. A. E. Permatasari, C. Chairunnisa, and ..., "Penguatan kapasitas kader melalui gerakan 'Aisyiyah Sehat (GRASS) sebagai upaya pencegahan penyakit tidak menular dan stunting, serta peningkatan kesehatan ...," J. Masy. LPPM UMJ, no. September, 2019.

[19] T. A. E. Permatasari, "Pengaruh Pola Asuh Pembrian Makan Terhadap Kejadian Stunting Pada Balita," J. Kesehat. Masy. Andalas, vol. 14, no. 2, p. 3, 2021.

[20] S. N. Jamil and A. Subiyatin, "Hubungan Riwayat Imunisasi dengan Status Gizi Balita," J. Bidan Cerdas, vol. 2, no. 3, pp. 132-138, 2020.

[21] I. Picauly and S. M. Toy, "Analisis Determinan Dan Pengaruh Stunting Terhadap Prestasi Belajar Anak Sekolah Di Kupang Dan Sumba Timur, Ntt,” J. Gizi dan Pangan, vol. 8, no. 1, p. 55, 2013.

[22] Jasman, A. Kartini, and Martini, "Faktor Risiko Kejadian Stunting Pada Anak Usia 12-36," Visikes, vol. 19, no. 1, pp. 72-82, 2020.

[23] N. syamsiah Risna Melina Rumahorbo, "Faktor-Faktor Yang Mempengaruhi Tumbuh Kembang Balita Di Wilayah Kerja Puskesmas Pancur Batu Kabupaten Deli Serdang Tahun 2019," Chmk Heal. J., vol. 4, no. April, pp. 158-165, 2020.

[24] N. Nasrul, "Pengendalian Faktor Risiko Stunting Anak Baduta Di Sulawesi Tengah," Promot. J. Kesehat. Masy., vol. 8, no. 2, pp. 131-146, 2019.

[25] H. Torlesse, A. A. Cronin, S. K. Sebayang, and R. Nandy, "Determinants of stunting in Indonesian children: Evidence from a cross-sectional survey indicate a prominent role for the water, sanitation and hygiene sector in stunting reduction," BMC Public Health, vol. 16, no. 1, pp. 1-11, 2016.

[26] Y. W. Firmansyah, "Faktor - Faktor Yang Mempengaruhi Kejadian Diare Pada Balita : Sebuah Review," Bul. Keslingmas, vol. 40, no. 1, pp. 1-6, 2021.

[27] D. W. Bayu, "Beberapa Faktor yang Berhubungan dengan Status Gizi Balita Stunting Author," CIRED - Open Access Proc. J., vol. 2017, no. July, pp. 1-67, 2014.

[28] V. M. Aguayo and P. Menon, "Stop stunting: Improving child feeding, women's nutrition and household sanitation in South Asia," Matern. Child Nutr., vol. 12, pp. 3-11, 2016.

[29] Zul Fikar Ahmad, "Balita Stunting Di Kabupaten Gorontalo," J. Ilm. Umum dan Kesehat. Aisyiyah, vol. 4, no. 2, p. 93, 2019.

[30] Indah Budiastutik and Muhammad Zen Rahfiludin, "Faktor Risiko Stunting pada anak di Negara Berkembang," Amerta Nutr., vol. 3, no. 3, pp. 122-129, 2019.

[31] W. Lestari, A. Margawati, and Z. Rahfiludin, "Faktor risiko stunting pada anak umur 6-24 bulan di kecamatan Penanggalan kota Subulussalam provinsi Aceh," J. Gizi Indones. (The Indones. J. Nutr., vol. 3, no. 1, pp. 37-45, 2014.

[32] S. Bening, A. Margawati, and A. Rosidi, "Asupan Zink, Riwayat ISPA dan Pengeluaran Pangan Sebagai Faktor Resiko Stunting Pada Anak Usia 2-5 tahun di Kota Semarang," J. Gizi, vol. 7, no. 1, pp. 20-29, 2018.

[33] W. F. Wellina, M. I. Kartasurya, and M. Z. Rahfilludin, "Faktor risiko stunting pada anak usia 6 12 bulan," J. Gizi Indones., vol. 5, no. 1, pp. 55-61, 2016. 